\title{
Effects of modified atmosphere, associated with masterpack transport packaging, and refrigerated storage time on the quality characteristics of pork loin cuts
}

\author{
Alessandra F. Rosa ${ }^{\mathrm{a}}$, Mirele D. Poleti ${ }^{\mathrm{a}}$, Julio C.C. Balieiro ${ }^{\mathrm{a}}$, Marcelo C. \\ CÉSAR ${ }^{\text {a }}$, AND PAUlo J.A. Sobral ${ }^{\mathrm{a}}$ \\ ${ }^{\text {a }}$ College of Animal Science and Food Engineering, University of São Paulo, Pirassununga - SP, Avenida Duque \\ de Caxias Norte, 225, CEP 13635-900, Brazil \\ ${ }^{*}$ Corresponding author \\ afrosa@usp.br \\ TEL: $+55-19-3565-4278$ \\ FAX: $+55-19-3565-4105$
}

Received: 12 August 2012; Published online: 18 October 2013

\begin{abstract}
The objective of this research was to study the effects of modified atmosphere, associated with masterpack transport packaging, and refrigerated storage time on the quality characteristics of pork loin cuts. Cuts of pork loin were packaged in trays, covered with poly(vinyl chloride) film. The trays were placed in a masterpack (MP), containing three gas compositions: A) $75 \% \mathrm{O}_{2}: 25 \% \mathrm{CO}_{2}$, B) $50 \% \mathrm{O}_{2}: 50 \% \mathrm{CO}_{2}$ or C) $100 \% \mathrm{CO}_{2}$, and stored at $2{ }^{\circ} \mathrm{C}$. Samples were taken after $1,8,15$, and 22 days of storage, and evaluated for numerous shelf life traits. The development of Psychrotrophic aerobic bacteria and Pseudomonas spp. was found from the $15^{\text {th }}$ day of storage. There was a significant treatment effect for some of the considered parameters, such as $\mathrm{pH}(\mathrm{P}<0.05)$ and color $\left(\mathrm{L}^{*}(\mathrm{P}<\right.$ $0.07)$, a* $(\mathrm{P}<0.07)$ and $\left.\mathrm{b}^{*}(\mathrm{P}<0.01)\right)$. There was a significant interaction $(\mathrm{P}<0.01)$ for the TBARS values. It can be concluded, from the microbiological point of view, that the use of modified atmospheres containing $25 \%$ to $100 \% \mathrm{CO}_{2}$ promotes the conservation of meat for up to 15 days of storage under refrigeration. From the point of view of color, atmospheres containing $75 \% \mathrm{O}_{2}: 25 \%$ $\mathrm{CO}_{2}$ and $50 \% \mathrm{O}_{2}: 50 \% \mathrm{CO}_{2}$ ensure the color of packaged pork meat when stored at $2{ }^{\circ} \mathrm{C}$ for up to 15 days. From the point of view of lipid oxidation, packages with $100 \% \mathrm{CO}_{2}$ are recommended for storage periods of more than 15 days, whereas those with $75 \% \mathrm{O}_{2}: 25 \% \mathrm{CO}_{2}$ are recommended for storage periods of up to 8 days.
\end{abstract}

Keywords: pork meat; modified atmosphere; color; TBARS; shelf life

\section{Introduction}

The use of modified-atmosphere packaging has primarily been employed to extend shelf life of refrigerated meat. The use of modified atmospheres and masterpack transport packaging can be an improved way to package meat for the retail market. According to (Jeremiah, 2001), a modified atmosphere is necessary to efficiently use the masterpack packages that are associated with display-ready meat packages in order to extend the storage time, which makes centralization of the distribution process easier.

Changes in color, microbial growth and lipid oxidation are the main factors that affect meat shelf life and, consequently, consumer acceptance (Jakobsen \& Bertelsen, 2000). Those factors are strongly influenced by the initial meat quality, 
the kind of package used, and the storage conditions (Sarantópoulos et al., 2002; Zhou, Xu, \& Liu, 2010).

Currently, the most used modified atmospheres combine convenient oxygen concentrations $\left(\mathrm{O}_{2}\right)$ for initial maintenance of meat color and convenient concentrations of carbon dioxide $\left(\mathrm{CO}_{2}\right)$ for conservation against microbial growth (Viana, Gomide, \& Vanetti, 2005; Lund, Lametsch, Hviid, Jensen, \& Skibsted, 2007; Sandhya, 2010; Schirmer \& Langsrud, 2010). According to Jakobsen and Bertelsen (2000), oxygen levels higher than $20 \%$ are needed to promote the maintenance of meat color; however, atmospheres containing oxygen concentrations above $55 \%$ do not impart any additional benefits to the stability of the meat color. It is already known that high $\mathrm{O}_{2}$ concentrations may negatively impact the oxidative stability of muscle lipids and cause a rapid development of meat rancidity, affecting meat quality attributes (Clausen, Jakobsen, Ertbjerg, \& Madsen, 2009; Lagerstedt, Lundstrom, \& Lindahl, 2011). Lipid oxidation is normally a slow process compared with meat discoloration or microbial growth (Zhao, Wells, \& McMillin, 1994). But, it can be considered as a limiting factor when these others deterioration mechanisms have been suppressed (Pearson, Gray, Wolzak, \& Horenstein, 1983) as in the case of packaged meat in a modified atmosphere. Research on modifiedatmosphere packaging has focused on discovering the correct mix of gases that will maximize initial color, provide color stability, lengthen the useful life of the meat and, at the same time, minimize the microbial growth and the lipid oxidation (Mancini \& Hunt, 2005).

Therefore, the aim of this research was to study the effects of modified atmosphere, associated with masterpack transport packaging, and refrigerated storage time on the quality characteristics of pork loin cuts.

\section{Materials and Methods}

\subsection{Sampling, Packaging and storage}

Initially, 20 pigs with a live weight of $90 \pm 10$ $\mathrm{kg}$ were slaughtered in the slaughterhouse of the
University of São Paulo, campus of Pirassununga (Brazil), after a 14 hour fasting period, following the humanitarian slaughter law practices in place in Brazil (Rosa, Sobral, Lima, \& Gomes, 2001). Immediately after slaughter, the carcasses were stored at $0-2{ }^{\circ} \mathrm{C}$ for rigor mortis development and resolution. They remained in cold storage for a 24 hour period.

To control the quality of meat, the $\mathrm{pH}$ and the temperature were determined 1, 6 and 24 hours post mortem in the Longissimus dorsi muscle between the $10^{t h}$ and the $11^{\text {th }}$ right carcass ribs. Thus, 18 carcasses were selected considering $\mathrm{pH}$ 1 hour $\geq 6.0$ and a $\mathrm{pH}-24$ hours between 5.3 and 5.6 (Buys, 2004). The Longissimus dorsi (LD) muscles were removed from the carcasses and sliced into cuts of approximately $2.5 \mathrm{~cm}$ thick. All cuts were mixed inside a plastic bag and samples were taken randomly, to avoid an animal effect.

Three cuts, weighted individually, were put into identified expanded polystyrene trays, previously sterilized, with a purge absorbent (SECA MEAT - PAD, Techno Paper - Brazil). The pH and color $\left(\mathrm{L}^{*}, \mathrm{a}^{*}\right.$ and $\left.\mathrm{b}^{*}\right)$ were measured and the trays were covered with poly(vinyl chloride) (PVC) film (thickness $=6.8 \pm 0.6 \mathrm{~mm}$; and Oxygen permeability $\left(\mathrm{PO}_{2}\right)$ of $650 \mathrm{~cm}^{3} \mathrm{~m}^{-2} \mathrm{~h}^{-1}$ at $23{ }^{\circ} \mathrm{C}$ ) (Cayuela, Gil, Banon, \& Garrido, 2004) and then, packaged in masterpack transport containers (6 trays per masterpack). The masterpack dimensions were $78.5 \times 48.5 \mathrm{~cm}$, with a 0.35 $\mathrm{m}^{-2}$ permeation area and a multilayer film made with EVA (ethylene vinyl-acetate), LDPE (lowdensity polyethylene) and PVDC [poly(vinyliden chloride)], which gave a high barrier to $\mathrm{O}_{2}$ and water vapor. The main properties of this film are as follows (according to the manufacturer, Cryovac): thickness, from 48 to $62 \mu \mathrm{m}$; permeability rate (maximum) to $\mathrm{O}_{2}$ of $30 \mathrm{~cm}^{3} \cdot \mathrm{m}^{2}$.day ${ }^{-1}$ (1 atm / $\left.23{ }^{\circ} \mathrm{C} / 0 \% \mathrm{RH}\right)$; and a permeability rate (maximum) to water vapor of $10 \mathrm{~g} \mathrm{H}_{2} \mathrm{O} / \mathrm{m}^{2}$.day (1 atm / $\left.38^{\mathrm{o}} \mathrm{C} / 90 \% \mathrm{RH}\right)$.

The masterpack packages were sealed with an automatic sealer (USA, model A 300, brand CVP) which was operated with two vacuum cycles and atmosphere injection at $3.5 \mathrm{kgf} / \mathrm{cm}^{2}$. Forty-eight masterpacks were assembled, resulting in 16 masterpacks per gas composition: A: $75 \% \quad \mathrm{O}_{2}: 25 \%$ $\mathrm{CO}_{2}$, B: $50 \% \mathrm{O}_{2}: 50 \% \mathrm{CO}_{2}$ and $\mathrm{C}: 100 \% \mathrm{CO}_{2}$.

\begin{tabular}{l|l|l|l} 
IJFS & October 2013 & Volume 2 & pages 167-179
\end{tabular} 
The ratio of gas volume (litres) to meat $(\mathrm{kg})$ was $3: 1$.

The masterpack packages were packed in plastic boxes and kept in a cold storage chamber at a controlled temperature of $2 \pm 1^{\underline{O}} \mathrm{C}$ during the entire experimental period.

\subsection{Experiment design}

The experimental period of storage was 22 days. During this period, at $1,8,15$ and 22 days of storage, 4 masterpacks of each gas composition were taken out of the cold storage chamber and opened, and the trays were sent to the laboratory for analysis.

\subsection{Gas Composition of masterpack}

The gas composition of the atmosphere inside a masterpack was determined directly in the packages using a needle, with a portable gas analyzer (Denmark, Dansensor brand, CheckPoint $\mathrm{O}_{2} / \mathrm{CO}_{2}$ model). This equipment had an electrochemical sensor to determine the $\mathrm{O}_{2}$ concentration and an infrared sensor for the $\mathrm{CO}_{2}$ concentration. The equipment was standardized using atmospheric gas.

\subsection{Microbiological Analysis of meat}

For the initial meat characterization, Salmonella sp., aerobic psychrotrophic bacteria, Pseudomonas spp., S. aureus and total coliform NMP counts were determined. During the experimental period, analyses to determine the presence of aerobic psychrotrophs and pseudomonades in the cuts were conducted at $1,8,15$ and 22 days of storage (Silva, Junqueira, \& Silveira, 2001).

\subsection{Physico-chemical analysis of meat}

\section{pH and Temperature}

The $\mathrm{pH}$ and the temperature of the meat were always measured, before other analysis, using a digital portable $\mathrm{pH}$ meter, with a glass electrode (Novatécnica - Brazil, model NT-PHP).

\section{Drip Loss}

The drip loss was determined by weighing the cuts before and after packaging and was expressed as a percentage (Honikel, 1998).

\section{Color}

The meat surface color was measured using a colorimeter (MiniScan XE model, Hunterlab), and the CIELab color scale $\left(\mathrm{L}^{*}, \mathrm{a}^{*}, \mathrm{~b}^{*}\right)$, where $\mathrm{L}^{*}$ represents the difference between light $\left(\mathrm{L}^{*}=100\right)$ and dark $\left(\mathrm{L}^{*}=0\right), \mathrm{a}^{*}$ represents the difference between green $\left(-\mathrm{a}^{*}\right)$ and red $\left(+\mathrm{a}^{*}\right)$, and $\mathrm{b}^{*}$ represents the difference between yellow $\left(+b^{*}\right)$ and blue $\left(-b^{*}\right)$. The measurements were taken in three different positions, immediately after opening the package. The colorimeter was calibrated according to the manufacturer's recommendations, operating with the following specifications: optical geometry 45/0, $25 \mathrm{~mm}$ opening diameter, observation angle of $10^{\circ}$ and illuminant D65. The $\mathrm{L}^{*}, \mathrm{a}^{*}$ and $\mathrm{b}^{*}$ parameters were obtained directly from the colorimeter allowing the calculation of the chrome $\left(\mathrm{C}^{*}\right)$ value (Equation 1 ) and of the hue $\left(\mathrm{h}^{*}\right)$ angle (Equation 2$)$.

$$
\begin{gathered}
C^{*}=\left(a^{* 2}+b^{* 2}\right)^{1 / 2} \\
h^{*}=t g^{-1}\left(b^{*} / a^{*}\right)
\end{gathered}
$$

\section{Lipid oxidation}

The lipid oxidation was measured according to the method of Vyncke (1970) and expressed as 2thiobarbituric acid reactive substances (TBARS) in $\mathrm{mg}$ malondialdehyde $\mathrm{kg}^{-1}$ meat.

\section{Statistical Analysis}

A completely randomized design in $3 \times 4$ factorial scheme $[3$ gas compositions ( $\mathrm{A}, \mathrm{B}$ and $\mathrm{C}$ ) and 4 storage times (1, 8, 15 and 22 days)], with 4 replicates for each gas composition $\mathrm{x}$ storage time of analysis, was used in this study for all variables (microbiological, $\mathrm{pH}$, meat colors, drip loss and lipid oxidation). The statistical analysis 
of results was carried out using the GLM procedure of Statistical Analysis System, version 9.1.3 (SAS Institute Inc., Cary, NC, USA).

\section{Results and discussion}

\subsection{Gas Composition}

The gas concentrations inside the masterpack packages were determined over the entire experimental period, i.e., 22 days at predetermined 7day intervals. In general, the storage time did not influence the gas compositions of $\mathrm{A}(75 \%$ $\left.\mathrm{O}_{2}: 25 \% \mathrm{CO}_{2}\right)$ or $\mathrm{B}\left(50 \% \mathrm{O}_{2}: 50 \% \mathrm{CO}_{2}\right)$, which stayed constant during the entire experimental period (Table 1). However, in packages with $100 \% \mathrm{CO}_{2}$, the presence of residual oxygen was observed and the $\mathrm{CO}_{2}$ concentration decreased over time, probably due to the masterpack package size. Moreover, the decrease in $\mathrm{CO}_{2}$ values inside the packages with composition $\mathrm{C}(100 \%$ $\mathrm{CO}_{2}$ ) can be attributed to $\mathrm{CO}_{2}$ absorption by the meat (Gill, 1996).

According to McMullen and Stiles (1991) and Sorheim, Nissen, and Nesbakken (1999) those losses can be up to $12.5 \%$. Buys (2004), in a study with pork loin samples packaged in different $\mathrm{CO}_{2}$ concentrations, observed a decrease in $\mathrm{CO}_{2}$ concentration for all compositions studied. In contrast, Mano, Pereda, and Fernando (2002) worked with pork meat packaged in atmospheres containing $100 \%$ air, $100 \%$ nitrogen, $20 \% \mathrm{CO}_{2}+80 \% \mathrm{O}_{2}$ and $40 \% \mathrm{CO}_{2}+60 \% \mathrm{O}_{2}$, and did not observe changes in the gas compositions up to 28 days of storage.

\subsection{Microbiological Analysis}

The results of the microbiological analysis on the raw meat did not show the presence of any of the tested microorganisms (Salmonella, Total Coliforms, S. Aureus and Pseudomonads) as a consequence of the safety techniques employed by the slaughter house of the campus of Pirassununga. However, the statistical analysis showed an interaction between gas composition and storage time $(\mathrm{P}<0.05)$ for aerobic psychrotrophic counts (Figure 1) and an effect of storage time $(\mathrm{P}<0.01)$ for Pseudomonads counts
(Figure 2), although these counts were low. For both bacteria groups, an important growth phase was observed only after the $15^{\text {th }}$ day.

The higher values for the aerobic psychrotrophic counts after 22 days $(>4.4 \log \mathrm{CFU} / \mathrm{g})$ of storage in the gas compositions containing $50 \% \mathrm{O}_{2}: 50 \%$ $\mathrm{CO}_{2}$ and $100 \% \mathrm{CO}_{2}$ suggest the presence of facultative aerobic microorganisms in the meat, which had better development conditions in the atmospheres with lower $\mathrm{O}_{2}$ concentrations. Wilkinson, Janz, Morel, Purchas, and Hendriks (2006), when working with pork meat packaged in atmospheres containing $100 \% \mathrm{CO}_{2}$, reported aerobic bacteria counts of approximately $3.16 \mathrm{log}$ $\mathrm{CFU} / \mathrm{g}$, that were close to those observed in this study. Sorheim et al. (1999) reported, after 3 weeks of storage, a total increase in the bacteria count from 2.3 to $5.5-6.0 \mathrm{log} \mathrm{CFU} / \mathrm{g}$ of meat. However, (Luno, Beltran, \& Roncales, 1998) studied the effect of gas compositions containing 20 or $50 \% \mathrm{CO}_{2}$ on the total psychrotrophic bacteria population in beef striploin samples, and observed that $20 \% \mathrm{CO}_{2}$ was not enough to maintain the microbiological acceptability of meat during the 4 weeks of storage.

Regarding the Pseudomonas counts, no effect $(\mathrm{P}>0.05)$ of the gas composition was observed. No growth in Pseudomonas was observed for meat samples taken on days 1,8 and 15 , staying $<1 \log \mathrm{CFUg}^{-1}$. But, for samples taken at day 22, the microorganism count attained 3.3 log CFUg-1. The Pseudomonas inhibition observed during the first 15 days agrees with the results found in the literature, indicating that the bacteria in this group were very sensitive to $\mathrm{CO}_{2}$ (Borch, KantMuermans, \& Blixt, 1996; Phillips, 1996; Cutter, 2002; Jayas \& Jeyamkondan, 2002; Liu, Yang, \& Li, 2006). Although the bacteriostatic effect of $\mathrm{CO}_{2}$ has been observed in meat, the results of this work demonstrated that the higher $\mathrm{CO}_{2}$ concentrations did not produce a larger inhibition of microbial growth, i.e., compositions $\mathrm{B}$ and $\mathrm{C}$ were not more effective than composition A. These results are in agreement with Gill (1996) and Viana et al. (2005), who state that $20 \% \mathrm{CO}_{2}$ is sufficient to inhibit microbial growth. According to Mano et al. (2002), Pseudomonas $s p$ growth in meat packaged in atmospheres containing $100 \% \mathrm{CO}_{2}$ may occur because of the difficulty in eliminating $\mathrm{O}_{2}$ from in- 
Effects of Modified Atmosphere on the pork loin quality characteristics | 171

Table 1: Mean Values and Standard Errors (SE) of Gas Compositions inside masterpacks during meat storage.

\begin{tabular}{|c|c|c|c|c|c|c|c|c|c|c|c|c|}
\hline \multirow{3}{*}{$\begin{array}{c}\text { Storage } \\
\text { Time } \\
\text { (days) }\end{array}$} & \multicolumn{4}{|c|}{$75 \% \mathrm{O}_{2}: 25 \% \mathrm{CO}_{2}$} & \multicolumn{4}{|c|}{$50 \% \mathrm{O}_{2}: 50 \% \mathrm{CO}_{2}$} & \multicolumn{4}{|c|}{$100 \% \mathrm{CO}_{2}$} \\
\hline & \multicolumn{2}{|c|}{$\mathrm{O}_{2}$} & \multicolumn{2}{|c|}{$\mathrm{CO}_{2}$} & \multicolumn{2}{|c|}{$\mathrm{O}_{2}$} & \multicolumn{2}{|c|}{$\mathrm{CO}_{2}$} & \multicolumn{2}{|c|}{$\mathrm{O}_{2}$} & \multicolumn{2}{|c|}{$\mathrm{CO}_{2}$} \\
\hline & Mean & S.E & Mean & S.E & Mean & S.E & Mean & S.E & Mean & S.E & Mean & S.E \\
\hline 1 & 72.0 & 0.8 & 20.8 & 2.8 & 49.4 & 0.8 & 42.2 & 2.8 & 2.0 & 0.8 & 91.4 & 2.8 \\
\hline 8 & 68.1 & 0.8 & 20.3 & 2.8 & 47.9 & 0.8 & 40.9 & 2.8 & 2.1 & 0.8 & 88.1 & 2.8 \\
\hline 15 & 67.2 & 0.8 & 20.4 & 2.8 & 46.9 & 0.8 & 39.9 & 2.8 & 2.6 & 1.0 & 86.4 & 3.2 \\
\hline 22 & 68.3 & 0.8 & 20.4 & 2.8 & 47.6 & 1.0 & 40.7 & 3.2 & 3.8 & 0.8 & 79.6 & 2.8 \\
\hline
\end{tabular}

Table 2: Mean Values and Standard Errors (SE) of TBARS values (mg malonaldehyde/kg meat).

\begin{tabular}{ccccccc}
\hline Storage & \multicolumn{6}{c}{ Gas Compositions } \\
\cline { 2 - 7 } Time & $75 \% \mathrm{O}_{2}:$ & $25 \% \mathrm{CO}_{2}$ & $50 \% \mathrm{O}_{2}:$ & $50 \% \mathrm{CO}_{2}$ & $100 \%$ & $\mathrm{CO}_{2}$ \\
\cline { 2 - 7 } (days) & Mean & $\mathrm{SE}$ & Mean & $\mathrm{SE}$ & Mean & $\mathrm{SE}$ \\
\hline 1 & 0.4 & 0.5 & 0.4 & 0.5 & 0.2 & 0.5 \\
8 & 2.4 & 0.5 & 2.6 & 0.5 & 1.5 & 0.5 \\
15 & 5.3 & 0.5 & 4.7 & 0.5 & 1.2 & 0.6 \\
22 & 12.4 & 0.5 & 15.2 & 0.6 & 6.7 & 0.5 \\
\hline
\end{tabular}

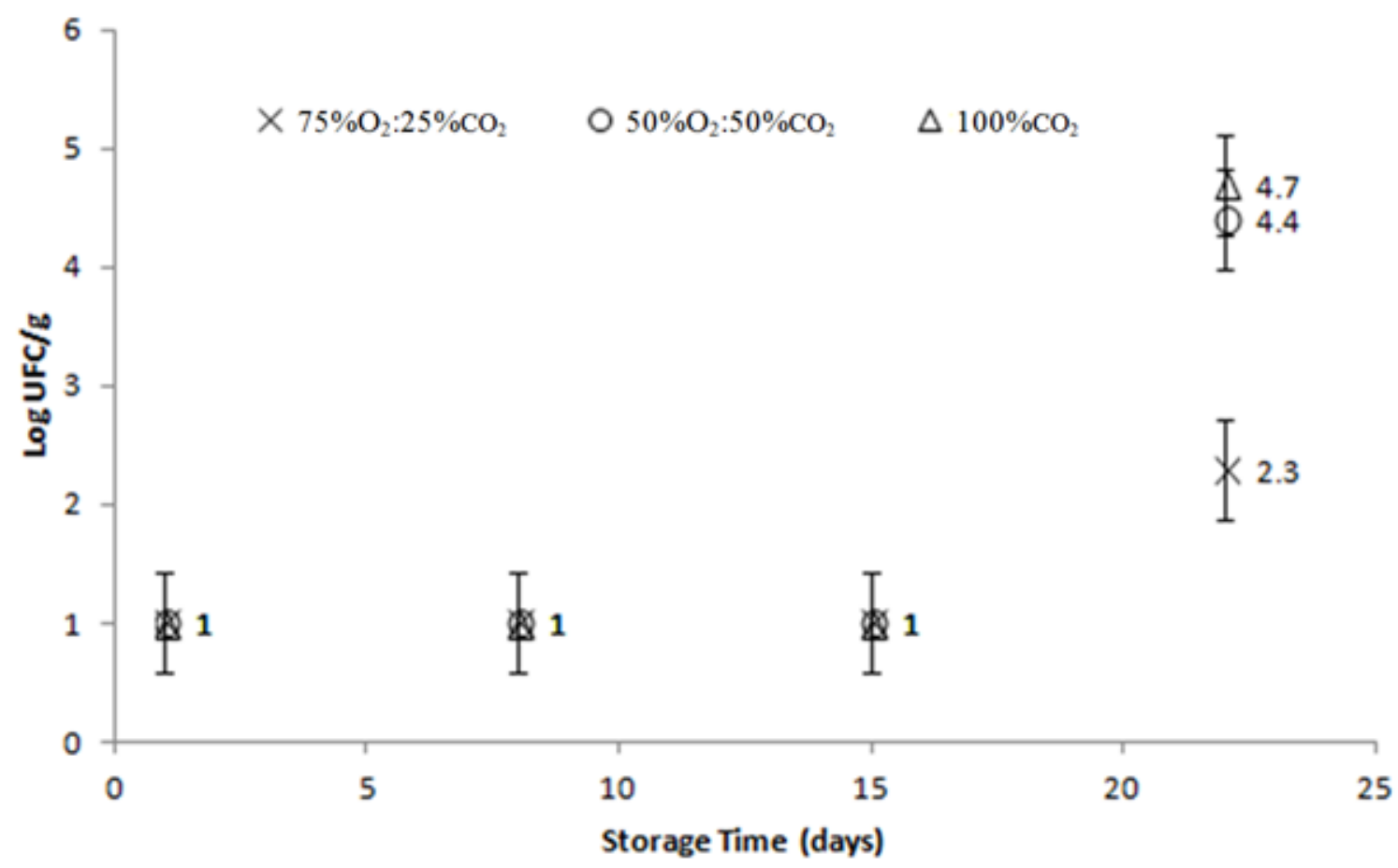

Figure 1: Aerobic Psychrotrophic counts of stored meat 


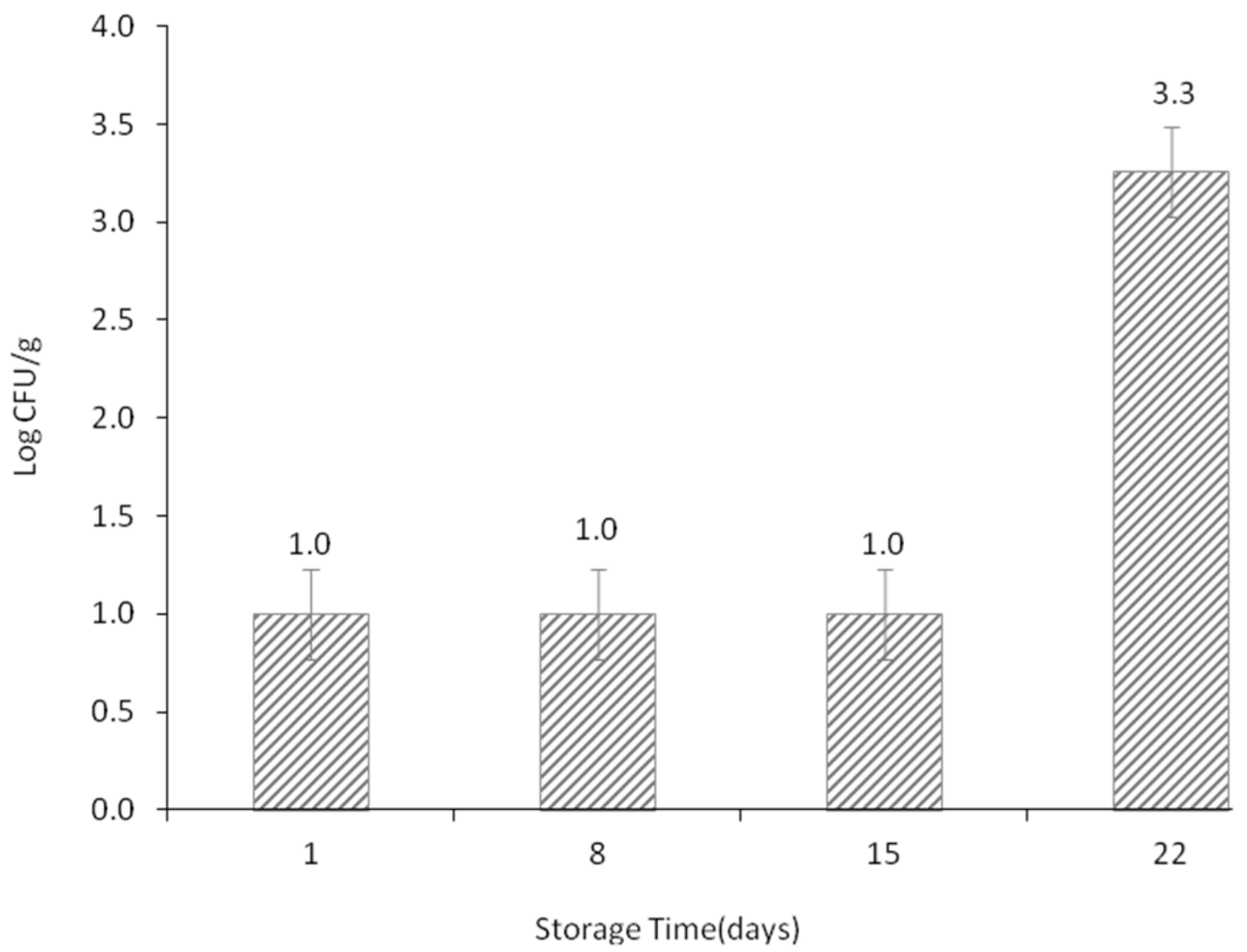

Figure 2: Pseudomonads counts of stored meat

side the packages; Pseudomonas sp are strictly aerobic bacteria.

It is still necessary to associate the results of the microorganism counting with the other meat quality evaluations to be able to infer which was the most appropriate gas composition. In any case, extending the shelf life to 15 days of storage is already a considerable improvement that produces economic gains over the normal storage conditions. The storage time of meat packed in expanded polystyrene trays with PVC film, without a modified atmosphere, is almost 7 days (Gray, Gomaa, \& Buckley, 1996).

\subsection{Physicochemical Analysis}

The $\mathrm{pH}$ of the meat was affected only by the storage time $(\mathrm{P}<0.01)$, so therefore, the results are only presented in Figure 3 as a function of time. A decline in the $\mathrm{pH}$ values was observed from the $1^{\text {st }}$ to the $8^{\text {th }}$ day of storage, with a slight increase in values on the subsequent days. McMullen and Stiles (1991) worked with pork meat packaged in atmospheres containing different $\mathrm{CO}_{2}$ concentrations, and reported a decrease in $\mathrm{pH}$ values in the first week of storage, without observing significant differences in $\mathrm{pH}$ values in the 9 subsequent weeks.

According to Jakobsen and Bertelsen (2000), when high levels of $\mathrm{CO}_{2}$ were applied to modified-atmosphere packaging, the $\mathrm{CO}_{2}$ concentration tends to decrease because of $\mathrm{CO}_{2}$ absorption by the meat, until the meat is saturated. The product generated in the process of $\mathrm{CO}_{2} \mathrm{ab}-$ sorption by the meat is carbonic acid, which, in turn, is dissociated into bicarbonate and hydro-

IJFS | October 2013 | Volume 2 | pages 167-179 
Effects of Modified Atmosphere on the pork loin quality characteristics $\mid 173$

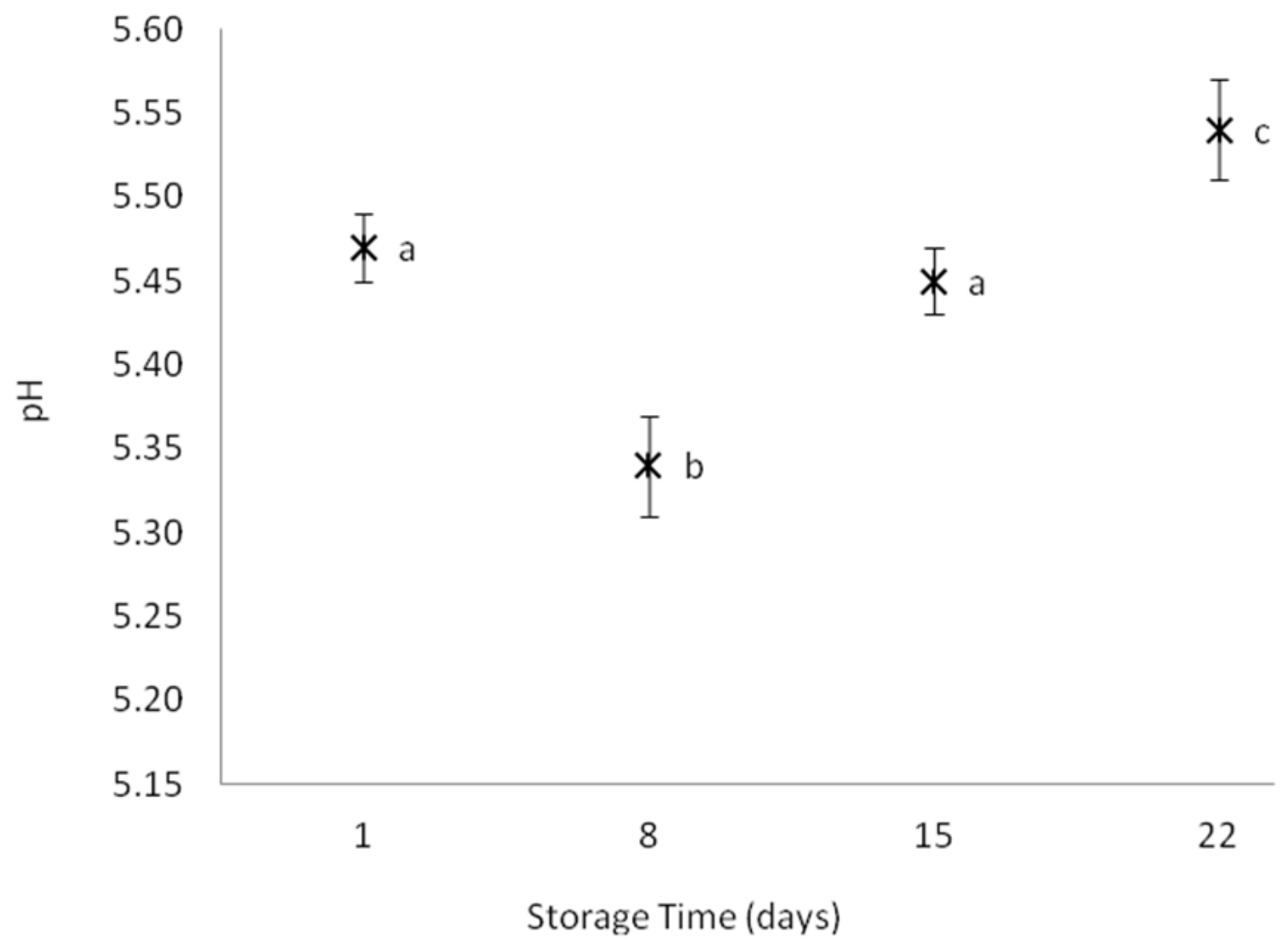

Figure 3: $\mathrm{pH}$ values of stored meat
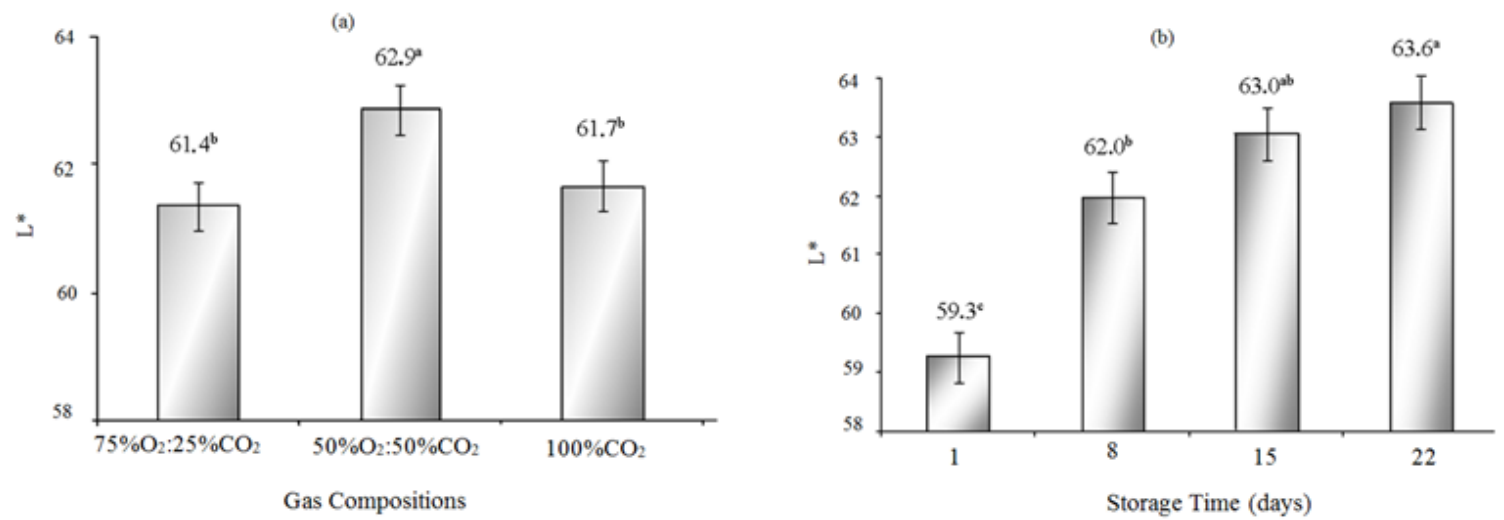

Figure 4: $\mathrm{L}^{*}$ values as a function of Gas Composition (a) and Storage Time (b) 
(a)

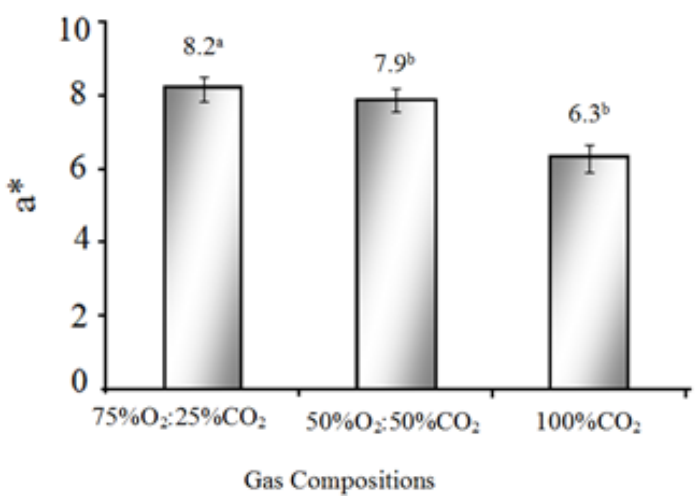

(b)

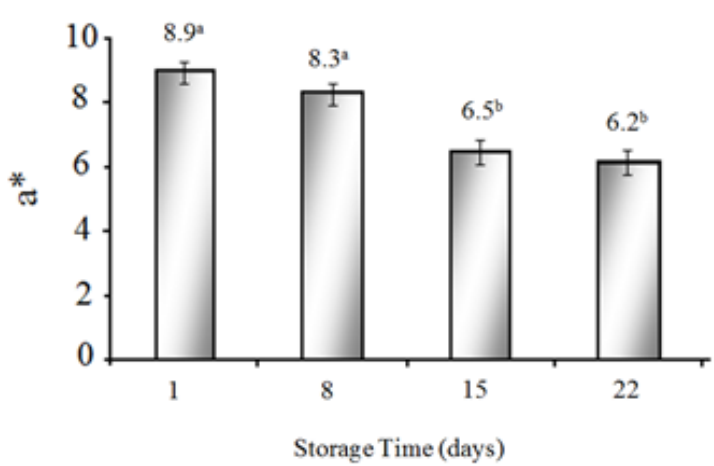

Figure 5: $\mathrm{a}^{*}$ values as a function of Gas Composition (a) and Storage Time (b)

gen ions. The formation of carbonic acid decreases the meat $\mathrm{pH}$, which explains the drop in $\mathrm{pH}$ values in the eighth day of storage. Because the meat has a relatively strong buffer system, the acidification resulting from the dissolved $\mathrm{CO}_{2}$ tends to be inhibited (Sorheim, Ofstad, \& Lea, 2004; Mano et al., 2002), which can be observed in the subsequent increase in the $\mathrm{pH}$ values after 15 and 22 days of storage.

No effect of the gas composition or storage time on the values of drip loss was observed from this study. The average value was $4.7 \%$, and ranged from $2.4 \%$ to $9.9 \%$. According to Gill (1996), losses of up to $5 \%$ from meat exudation can be expected. Jeremiah, Gibson, and Argonosa (1995) reported average drip loss values close to $4.5 \%$, and they also did not observe an increase in the drip loss values of pork loin cuts stored under $100 \% \mathrm{CO}_{2}$ during 15 weeks of storage. Cayuela et al. (2004) observed a slight increase in drip loss values during 13 days of storage, ranging from $3.5 \%$ to $7.6 \%$. Monahan et al. (1994) and Otto et al. (2006) could not find any evidence of a direct relationship between lipid oxidation and cell membrane degradation during the storage period, and therefore, no $\mathrm{CO}_{2}$ effect on meat water holding capacity was evidenced.

The study of colour parameters is very important because they are considered as quality signals by consumers (Resano et al., 2011). The results of this work showed that parameters $\mathrm{L}^{*}$ and $\mathrm{a}^{*}$ were affected by the gas composition $(\mathrm{P}<0.05)$ and the storage time $(\mathrm{P}<0.01)$, whereas the parameter $\mathrm{b}^{*}$ was affected only by the gas composition $(\mathrm{P}<0.01)$. Although there are differences in the objectively determined $L^{*}$ values, these differences were very small and could not be noticed visually. On the other hand, as can be observed in Figures $4 \mathrm{a}$ and $4 \mathrm{~b}$, there was a slight increase in $\mathrm{L}^{*}$ values during storage.

Jeremiah and Gibson (1997) worked with pork loin samples stored under $100 \% \quad \mathrm{CO}_{2}, \quad 70 \%$ $\mathrm{O}_{2}: 30 \% \mathrm{CO}_{2}$ and $100 \% \mathrm{~N} 2$ and determined that the $\mathrm{L}^{*}$ values were higher in the packaged samples containing a higher amount of $\mathrm{O}_{2}$. Sorheim, Erlandsen, Nissen, Lea, and Hoyem (1997) also observed that the values of $\mathrm{L}^{*}$ increased until the $7^{\text {th }}$ day and stabilized until the end of the experiment (21 days). On the other hand, Viana et al. (2005) worked with pork loin cuts packaged with $100 \% \mathrm{CO}_{2}, 99 \% \mathrm{CO}_{2}+1 \% \mathrm{CO}, 100 \% \mathrm{O}_{2}$ and $100 \% \mathrm{CO}+$ vacuum (after one hour of exposure), and a decrease in the values of $\mathrm{L}^{*}$ was observed during the 20 days of storage.

Concerning the values of $\mathrm{a}^{*}$, the cuts with compositions A and B had higher values (8.2 and 7.9 , respectively) than those of composition $\mathrm{C}$ (6.3) (Figure 5a). Visually, the cuts from compositions $\mathrm{A}$ and $\mathrm{B}$ showed a more pinkish color than the other one, which was expected because of the higher amount of oxygen in this composition, which keeps the myoglobin in its oxy- 


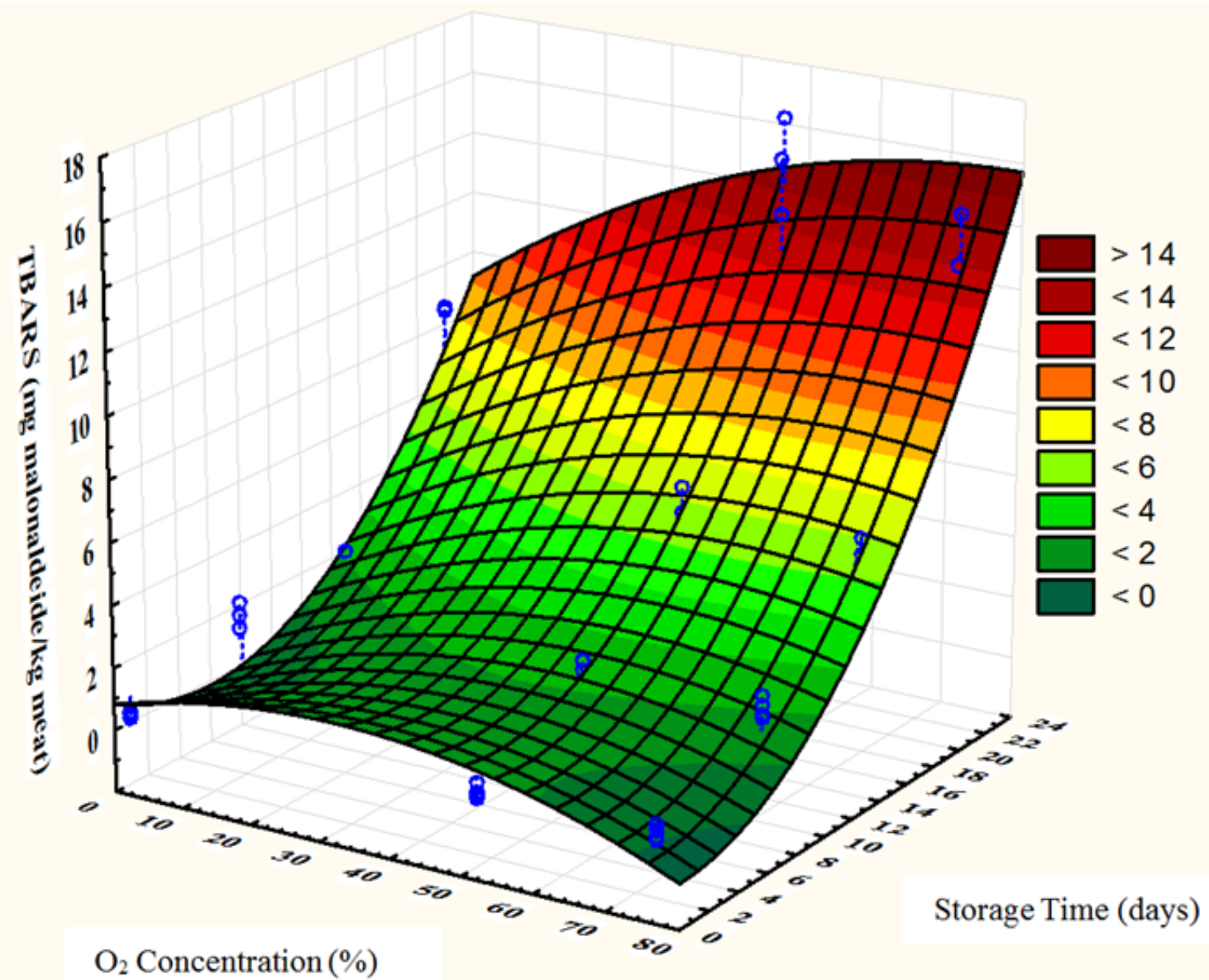

Figure 6: Response surface of TBARS values (mg malonaldehyde $/ \mathrm{kg}$ meat) as functions of $\mathrm{O}_{2}$ concentration (\%) and Storage Time (days) of packaged meat

genated form (oxymyoglobin) for a longer period of time. However, the results indicate that the increase in the oxygen concentration from $50 \%$ to $75 \%$ did not result in a color improvement. During the storage period, a decrease in the values of $a^{*}$ from 8.9 to 6.2 (Figure 5b) was observed, suggesting discoloration at the surface of the cuts. Some studies reported that the values of $a^{*}$ tend to decrease progressively during the storage period, independent of package type or gas composition, indicating that there is a negative correlation between the values of $\mathrm{a}^{*}$ and the storage time (Jeremiah \& Gibson, 2001; Viana et al., 2005). Sorheim et al. (1997) observed that packages with $0.5 \%$ and $1.0 \%$ residual oxygen had lower values of $\mathrm{a}^{*}$ for normal and not normal (Pale Soft Exudative) meat. Those authors suggested that low $\mathrm{O}_{2}$ concentrations promote the discoloration of the meat surface through metmyoglobin buildup.

According to Walker (1980), a hypothesis explaining the loss of color at the meat surface involves the bacteria, mainly the Pseudomonas sp., consuming the oxygen near or on the surface of the meat, promoting loss of meat color. As was observed in the present study, there was an exponential increase in both Pseudomonas sp. and aerobic psychotropic from the $15^{\text {th }}$ day of storage onwards (Figures 1 and 2), the same period when the values of $a^{*}$ dropped significantly, sug- 
gesting that this drop in value is connected to the growth of microorganisms, although the $\mathrm{pH}$ values changed very little (Figure 3).

The cuts packages under gas compositions $\mathrm{A}$ and $\mathrm{B}$ had higher values of $\mathrm{b}^{*}(\sim 16.8)$ than those packed under composition C (15.9). Lindahl, Lundstrom, and Tornberg (2001) observed that $86 \%$ of the variation in the values of $\mathrm{b}^{*}$ was associated with metamyoglobin present at the surface of the muscle. Under those conditions, the way to minimize this problem would be to store the meat at $0^{\circ} \mathrm{C}$, which, according to Gill (1996), reduces the formation of metmyoglobin.

For the $\mathrm{C}^{*}$ values, an effect of gas composition was observed, whereas for $\mathrm{h}^{*}$, an effect of storage time was observed. Lower values of $\mathrm{C}^{*}$ were observed in the cuts from composition C (17.3), and there was no difference between the cuts from compositions A and B (18.6). The values of $h^{*}$ increased from the $8^{\text {th }}(63.2)$ to the $15^{\text {th }}$ day of storage (68.6), becoming stable after that point. According to Lanari, Schaefer, and Scheller (1995), high values of $\mathrm{h}^{*}$, near 90, are associated with low values of $\mathrm{C}^{*}$ and indicate a brownish color of meat. Cayuela et al. (2004), in a study using pork loin packaged in a modified atmosphere containing $70 \% \quad \mathrm{O}_{2}: 30 \% \mathrm{CO}_{2}$, observed an increase in the values of $\mathrm{h}^{*}$ and $\mathrm{C}^{*}$ throughout the experimental period, which was 20 days. Even with higher $\mathrm{O}_{2}$ concentration atmospheres, they tended to have higher values of $\mathrm{C}^{*}$.

For the TBARS values, a significant effect for the composition $\mathrm{x}$ storage time interaction was found $(\mathrm{P}<0.01)$. The lipid oxidation may be sensorial or chemically determined through substances that are reactive to Thiobarbituric acid (TBARS), which is a predictor strongly connected to rancidity (McMillin, 2008). According to Campo et al. (2006), a TBARS value of approximately $2.0 \mathrm{mg}$ malonaldehyde $/ \mathrm{kg}$ of meat was considered as the limit for consumer acceptance, i.e., above such a value, smell and rancidity are already very perceptible. At 8 days of storage (Table 2), the samples coming from compositions $\mathrm{A}$ and $\mathrm{B}$ had TBARS values higher than 2 (2.4 and $2.6 \mathrm{mg}$ malonaldehyde $/ \mathrm{kg}$ of sample, respectively), probably due to the oxygen inside the packages which promoted an increase in the lipid oxidation rates (Pearson et al.,
1983; Gray et al., 1996; Guillen-Sans \& GuzmanChozas, 1998; Campo et al., 2006; McMillin, 2008; Clausen et al., 2009). It is interesting to note that the meat from composition $\mathrm{C}$ only had TBARS values above $2 \mathrm{mg}$ of malonaldehyde $/ \mathrm{kg}$ of sample after 22 days of storage, confirming what was described by the above cited authors. The results from the TBARS analysis enable us to suggest that the use of concentrations higher than $20 \% \mathrm{CO}_{2}$ and associated with high $\mathrm{O}_{2}$ concentrations, may promote a higher lipid oxidation rate in meat. In such a context, the ideal situation would be the use of atmospheres with $75 \% \mathrm{O}_{2}: 25 \% \mathrm{CO}_{2}$ for shorter periods of storage of up to 8 days or atmospheres of $100 \% \mathrm{CO}_{2}$ for longer periods of up to 22 days.

Jakobsen and Bertelsen (2000) worked with pork loin cuts packaged in atmospheres with $80 \%$ $\mathrm{O}_{2}: 20 \% \mathrm{CO}_{2}$ and measured TBARS values ranging from 2 to $18 \mathrm{mg}$ of malonaldehyde $/ \mathrm{kg}$ of meat for 10 days of storage. Those authors reported that to maintain a good appearance and a minimum level of lipid oxidation for the meat, a $20 \%$ $\mathrm{O}_{2}$ concentration was necessary. These same authors reported that the most important factor in maintaining the red color of meat (oxymyoglobin) and low lipid oxidation levels was the storage temperature.

Another approach to analyzing the results of the TBARS study is shown in Figure 6. In this case, because both factors were considered as quantitative, regression analyses were performed using a response surface model. The quadratic model (Equation 3) was enough to explain the TBARS variation, and all of the regression coefficients were significantly different from zero $(\mathrm{P}<0.01)$. The values of TBARS increased during storage, but treatment $\mathrm{C}$ was more efficient against lipid oxidation than treatments $\mathrm{A}$ and $\mathrm{B}$. There was a relationship between the concentration of $\mathrm{O}_{2}$ and the TBARS values (Martinez, Djenane, Cilla, Beltran, \& Roncales, 2005).

$$
\begin{aligned}
& \text { TBARS }=0.8454+0.0665 O_{2}-0.339 S T-\ldots \\
& \ldots 0.0011 O_{2}^{2}+0.0041 O_{2} S T+0.0286 S T^{2} \\
& \left(R^{2}=0.90\right)
\end{aligned}
$$


where $\mathrm{O}_{2}$ is the concentration of that gas, and ST means storage time, according Figure 6.

\section{Conclusions}

Taking a global point of view, the use of modified atmospheres containing $25 \%$ to $100 \% \mathrm{CO}_{2}$ promotes the conservation of meat for up to 15 days of storage under refrigeration. Packages with $100 \% \mathrm{CO}_{2}$ are recommended for storage periods of more than 15 days, whereas those with $75 \% \mathrm{O}_{2}: 25 \% \mathrm{CO}_{2}$ are recommended for storage periods of up to 8 days.

\section{Acknowledgements}

To the FAPESP, for the grants (06/54338-9) and fellowships (Dr: 06/50025-6, IC: 07/52020-4 and 07/52021-0).

\section{References}

Borch, E, KantMuermans, M., \& Blixt, Y. (1996). Bacterial spoilage of meat and cured meat products. International Journal of Food Microbiology, 33(1), 103-120. doi:10.1016/0168-1605(96)01135-X

Buys, E. (2004). Colour changes and consumer acceptability of bulk packaged pork retail cuts stored under $\mathrm{O}_{2}, \mathrm{co}_{2}$ and $\mathrm{n}_{2}$. Meat Science, 68(4), 641-647. doi:10.1016/j . meatsci.2004.05.017

Campo, M., Nute, G., Hughes, S., Enser, M, Wood, J., \& Richardson, R. (2006). Flavour perception of oxidation in beef. Meat Science, 72(2), 303-311. doi:10 . $1016 / \mathrm{j}$. meatsci.2005.07.015

Cayuela, J., Gil, M., Banon, S, \& Garrido, M. (2004). Effect of vacuum and modified atmosphere packaging on the quality of pork loin. European Food Research And Technology, 219(4), 316-320. doi:10.1007/s00217004-0970-x

Clausen, I., Jakobsen, M., Ertbjerg, P., \& Madsen, N. T. (2009). Modified atmosphere packaging affects lipid oxidation, myofibrillar fragmentation index and eating quality of beef. Packaging Technology and Science, 22(2), 85-96. doi:10.1002/pts.828
Cutter, C. (2002). Microbial control by packaging: a review. Critical Reviews in Food Science and Nutrition, 42(2), 151-161. doi:10. $1080 / 10408690290825493$

Gill, C. (1996). Extending the storage life of raw chilled meats. Meat Science, $43(\mathrm{~S})$, S99 S109. doi:10.1016/0309-1740(96)00058-7

Gray, J. I., Gomaa, E. A., \& Buckley, D. J. (1996). Oxidative quality and shelf life of meats. Meat Science, 43(1), 111-123. doi:10.1016/0309-1740(96)00059-9

Guillen-Sans, R, \& Guzman-Chozas, M. (1998). The thiobarbituric acid (tba) reaction in foods: a review. Critical Reviews in Food Science and Nutrition, 38(4), 315-330.

Honikel, K. (1998). Reference methods for the assessment of physical characteristics of meat. Meat Science, 49(4), 447-457. doi:10.1016/S0309-1740(98)00034-5

Jakobsen, M, \& Bertelsen, G. (2000). Colour stability and lipid oxidation of fresh beef. development of a response surface model for predicting the effects of temperature, storage time, and modified atmosphere composition. Meat Science, 54(1), 49-57. doi:10. 1016/S0309-1740(99)00069-8

Jayas, D., \& Jeyamkondan, S. (2002). Modified atmosphere storage of grains meats fruits and vegetables. Biosystems Engineering, 82(3), 235-251. doi:10. 1006 / bioe. 2002. 0080

Jeremiah, L. (2001). Packaging alternatives to deliver fresh meats using short- or longterm distribution. Food Research International, 34(9), 749-772. doi:10.1016/S09639969(01)00096-5

Jeremiah, L., \& Gibson, L. (2001). The influence of packaging and storage time on the retail properties and case-life of retail-ready beef. Food Research International, 34(7), 621631. doi:10.1016/S0963-9969(01)00080-1

Jeremiah, L., \& Gibson, L. (1997). The influence of storage and display conditions on the color stability of display-ready pork loin roasts. Meat Science, 47(1-2), 1-16. doi:10. 1016/S0309-1740(97)00036-3

Jeremiah, L., Gibson, L., \& Argonosa, G. (1995). The influence of inherent muscle quality upon the storage life of chilled pork stored in $\mathrm{CO}_{2}$ at -1.5-degrees-c. Food Research In- 
ternational, 28(1), 51-59. doi:10.1016/ 0963-9969(95)93331-N

Lagerstedt, A., Lundstrom, K., \& Lindahl, G. (2011). Influence of vacuum or high-oxygen modified atmosphere packaging on quality of beef $m$ longissimus dorsi steaks after different ageing times. Meat Science, 87(2), 101-106. doi:10.1016/j.meatsci.2010.08.010

Lanari, M., Schaefer, D., \& Scheller, K. (1995). Dietary vitamin-e supplementation and discoloration of pork bone and muscle following modified atmosphere packaging. Meat Science, 41(3), 237-250. doi:10.1016/ 0309-1740(95)00006-7

Lindahl, G, Lundstrom, K, \& Tornberg, E. (2001). Contribution of pigment content, myoglobin forms and internal reflectance to the colour of pork loin and ham from pure breed pigs. Meat Science, 59(2), 141-151. doi:10.1016/S0309-1740(01)00064-X

Liu, F, Yang, R., \& Li, Y. (2006). Correlations between growth parameters of spoilage micro-organisms and shelf-life of pork stored under air and modified atmosphere at -2, 4 and 10 degrees c. Food $\mathrm{Mi}$ crobiology, 23(6), 578-583. doi:10.1016/j. fm.2005.10.002

Lund, M. N., Lametsch, R., Hviid, M. S., Jensen, O. N., \& Skibsted, L. H. (2007). Highoxygen packaging atmosphere influences protein oxidation and tenderness of porcine longissimus dorsi during chill storage. Meat Science, 77(3), 295-303. doi:10.1016/j . meatsci.2007.03.016

Luno, M, Beltran, J., \& Roncales, P. (1998). Shelf-life extension and colour stabilisation of beef packaged in a low o-2 atmosphere containing co: loin steaks and ground meat. Meat Science, 48(1-2), 75-84. doi:10.1016/ S0309-1740(97)00078-8

Mancini, R., \& Hunt, M. (2005). Current research in meat color. Meat Science, 71 (1), 100-121. 51 $1^{\text {st }}$ International Congress of Meat Science and Technology $\left(51^{\text {st }}\right.$ IcoMST), Baltimore, MD, AUG 07-12, 2005. doi:10.1016/j.meatsci.2005.03.003

Mano, S., Pereda, J., \& Fernando, G. (2002). Aumento da vida útil e microbiologia da carne suína embalada em atmosfera modi- ficada. Ciencia e Tecnologia de Alimentos, 22. doi:10.1590/S0101-20612002000100002

Martinez, L, Djenane, D, Cilla, I, Beltran, J., \& Roncales, P. (2005). Effect of different concentrations of carbon dioxide and low concentration of carbon monoxide on the shelf-life of fresh pork sausages packaged in modified atmosphere. Meat Science, 71 (3), 563-570. doi:10.1016/j.meatsci.2005.04.041

McMillin, K. W. (2008). Where is map going? a review and future potential of modified atmosphere packaging for meat. Meat Science, 80(1), 43-65. 54th International Congress of Meat Science and Technology, Cape Town, SOUTH AFRICA, AUG 1015, 2008. doi:10.1016/j.meatsci.2008.05.028

McMullen, L., \& Stiles, M. (1991). Changes in microbial parameters and gas-composition during modified atmosphere storage of fresh pork loin cuts. Journal of Food Protection, 54(10), 778-783.

Monahan, F., Gray, J., Asghar, A, Haug, A, Strasburg, G., Buckley, D., \& Morrissey, P. (1994). Influence of diet on lipid oxidation and membrane-structure in porcine muscle microsomes. Journal of Agricultural and Food Chemistry, 42(1), 59-63. doi:10. 1021/jf00037a009

Otto, G, Roehe, R, Looft, H, Thoelking, L, Henning, M, Plastow, G., \& Kalm, E. (2006). Drip loss of case-ready meat and of premium cuts and their associations with earlier measured sample drip loss, meat quality and carcass traits in pigs. Meat Science, 72(4), 680-687. doi:10.1016/j . meatsci . 2005.10.001

Pearson, A., Gray, J., Wolzak, A., \& Horenstein, N. (1983). Safety implications of oxidized lipids in muscle foods. Food Technology, $37(7), 121-129$.

Phillips, C. A. (1996). Review: Modified Atmosphere Packaging and its effects on the microbiological quality and safety of produce. International Journal of Food Science and Technology, 31, 463-479. doi:10.1046/j . 1365-2621.1996.00369.x

Resano, H., Perez-Cueto, F. J. A., de Barcellos, M. D., Veflen-Olsen, N., Grunert, K. G., \& Verbeke, W. (2011). Consumer satisfaction with pork meat and derived products in five 
european countries. Appetite, 56(1), 167170. doi:10.1016/j.appet.2010.10.008

Rosa, A., Sobral, P., Lima, C., \& Gomes, J. (2001). Determinação das características físico-químicas da carne de suínos em fase de crescimento. Revista TeCarnes, 3(1), 218.

Sandhya. (2010). Modified atmosphere packaging of fresh produce: current status and future needs. LWT-Food Science and Technology, 43(3), 381-392. doi:10.1016/j.lwt.2009.05. 018

Sarantópoulos, C., Oliveira, L., Padula, M., Coltro, L., Alves, R., \& Garcia, E. (2002). Embalagens plásticas flexíveis. principais polímeros e avaliação de propriedades. Campinas: CETEA/ITAL, 179.

Schirmer, B. C., \& Langsrud, S. (2010). A dissolving $\mathrm{CO}_{2}$ headspace combined with organic acids prolongs the shelf-life of fresh pork. Meat Science, 85(2), 280-284. doi:10. 1016/j.meatsci.2010.01.013

Silva, N., Junqueira, V., \& Silveira, N. (2001). Manual de microbiologia de alimentos. $2^{e d}$. São Paulo: Varela, 317.

Sorheim, O, Ofstad, R, \& Lea, P. (2004). Effects of carbon dioxide on yield, texture and microstructure of cooked ground beef. Meat Science, 67(2), 231-236. doi:10.1016/j . meatsci.2003.10.010

Sorheim, O, Erlandsen, T, Nissen, H, Lea, P, \& Hoyem, T. (1997). Effects of modified atmosphere storage on colour and microbiological shelf life of normal and pale, soft and exudative pork. Meat Science, 47(12), 147-155. doi:10.1016/S0309-1740(97) 00050-8

Sorheim, O, Nissen, H, \& Nesbakken, T. (1999). The storage life of beef and pork packaged in an atmosphere with low carbon monoxide and high carbon dioxide. Meat Science, 52(2), 157-164. doi:10.1016/S03091740(98)00163-6

Viana, E., Gomide, L., \& Vanetti, M. (2005). Effect of modified atmospheres on microbiological, color and sensory properties of refrigerated pork. Meat Science, 71 (4), 696705. doi:10.1016/j.meatsci.2005.05.013

Vyncke, W. (1970). Direct Determination of the Thiobarbituric Acid Value in Trichloracetic
Acid Extracts of Fish as a Measure of Oxidative Rancidity. Fett-lipid, 72, 1084-1087. doi:10.1002/lipi.19700721218

Walker, H. (1980). Effects of microflora on fresh meat colour. In: Proceedings $33^{\text {rd }}$ reciprocal meat conference, West Lafayette, Indiana, USA.

Wilkinson, B., Janz, J., Morel, P., Purchas, R., \& Hendriks, W. (2006). The effect of modified atmosphere packaging with carbon monoxide on the storage quality of masterpackaged fresh pork. Meat Science, 73(4), 605-610. doi:10.1016/j.meatsci.2006.03.001

Zhao, Y., Wells, J. H., \& McMillin, K. W. (1994). Applications of dynamic modified atmosphere packaging systems for fresh red meats: review. Journal of Muscle Foods, 5, 299-328. doi:10.1111/j.1745-4573. 1994. tb00538.x

Zhou, G. H., Xu, X. L., \& Liu, Y. (2010). Preservation technologies for fresh meat - a review. Meat Science, $86(1, \mathrm{SI}), 119-128$. doi:10.1016/j.meatsci.2010.04.033 